\title{
O "TIME DO POVO" E O DISCURSO DA INCLUSÃO PERIFÉRICA: CIS-HETERONORMATIVIDADE, FUTEBOL, IDEOLOGIA
}

\author{
MATHEUS DA SILVA MEDEIROS ${ }^{1}$ \\ MÓNICA G. ZOPPI-FONTANA ${ }^{2}$
}
Instituto de Estudos da Linguagem, Universidade Estadual de Campinas
Rua Sérgio Buarque de Holanda, $n^{0} 571$ - 13083-859
Cidade Universitária Zeferino Vaz - Campinas - SP - Brasil
medeirosmath@outlook.com, monzoppi@unicamp.br

\begin{abstract}
Resumo. Neste trabalho, apresentamos as reflexões que desenvolvemos em nossa pesquisa (MEDEIROS, 2019), que teve como objeto de estudo a emergência, nas redes sociais, das autointituladas torcidas livres e queer de futebol. '̀ luz da perspectiva discursiva, sinalizamos os efeitos de naturalização e evidência que configuram a circulação de sentidos cisheteronormativos no campo discursivo do futebol, bem como analisamos um manifesto publicado pelo $S$. C. Corinthians no Twitter, em defesa do fim do grito de "bicha" nos estádios. Por fim, refletimos sobre como a fundação de uma pretensa unidade consensual, como forma de arrefecer a luta de classes, é uma tentativa de "inclusão periférica" (JUNQUEIRA, 2015), que não desestabiliza ou questiona os sentidos normativos e a exclusão operada pela ordem cis-heteronormativa.
\end{abstract}

Palavras-chave: Análise do Discurso; Cis-heteronormatividade; Ideologia; Inclusão periférica.

\begin{abstract}
In this work, we discuss the results obtained by our research (MEDEIROS, 2019), whose study object was the emergency of movements of auto-claimed queer football fans on social media. In the light of discursive approach, our work addresses naturalization/evidence effects that constitute the relationship between cis-heteronormative senses and football, and analyzes a manifest, published by $S$. C. Corinthians on Twitter, that advocates for the end of the "faggot" scream in football games. Finally, we analyze how the foundation of an alleged consensual unity, as a form of alleviate class struggle, is an attempt of "peripheral inclusion" (JUNQUEIRA, 2015), that does not destabilize or question the normative senses and the exclusion operated by the cis-heteronormative order.
\end{abstract}

Keywords: Discourse Analysis; Cis-heteronormativity; Ideology; Peripheral inclusion.

\footnotetext{
${ }^{1}$ Mestrando em Linguística/IEL-UNICAMP, bolsista CAPES.

${ }^{2}$ Docente do Departamento de Linguística/IEL-UNICAMP/CNPq.
} 


\section{INTRODUÇÃO}

Neste trabalho, apresentamos as reflexões que desenvolvemos em nossa pesquisa monográfica (MEDEIROS, 2019, no prelo), intitulada Torcida que canta, vibra e luta, desenvolvida a partir de projeto de Investigação Científica com apoio financeiro do CNPq. Em tal pesquisa, à luz dos pressupostos teóricos e metodológicos da Análise do Discurso materialista, em intersecção com os Estudos de Gênero, analisamos um corpus discursivo composto pela identidade visual, designação e postagens de páginas de torcidas autodenominadas queer e livres no Facebook ${ }^{3}$ : a QUEERlorado, a Palmeiras Livre, a Galo Queer e a Bambi Tricolor. Traçamos como objetivo analisar os deslizamentos e rupturas discursivas produzidas pelo questionamento à ordem de poder cis-heteronormativa, uma vez que o futebol historicamente construiu o homem cis-heterossexual como seu participante e interlocutor legítimo. (PINTO, 2017). Com isso, inscritas na modalidade de subjetivação da contraidentificação ${ }^{4}$, observamos a constituição pelas torcidas de um lugar de enunciação ${ }^{5}$ (ZOPPI-FONTANA, 2002, 2017) com visibilidade e legitimidade para denunciar a interdição histórica, em sua relação com a luta contra o silenciamento (ORLANDI, 2007) e com a denúncia dos dizeres cis-heteronormativos que constituem a evidência dos sentidos sobre pessoas LGBTI+ (lésbicas, gays, bissexuais, transexuais, travestis e intersexuais). A partir disso, afirmamos que a enunciação de sentidos positivos sobre si e o questionamento dos dispositivos cis-heteronormativos fundam regimes de enunciabilidade contradominantes que tornam possível a emergência dessas torcidas em meio aos processos históricos de dominação/subalternização que naturalizaram a exclusão de pessoas LGBTI+ do futebol.

$\mathrm{Na}$ esteira do trabalho que desenvolvemos, propomos neste artigo a análise de uma publicação realizada pelo perfil oficial do S. C. Corinthians no Twitter, em que o clube paulistano argumenta pelo fim do grito de "bicha" ecoado nos estádios, no momento em que o goleiro adversário realiza a cobrança do tiro de meta. Pretendemos analisar a construção discursiva do manifesto a partir da Análise do Discurso materialista, segundo a qual se entende que os acontecimentos têm uma materialidade histórica; isto é, devem ser compreendidos em sua relação com determinadas condições históricas, que possibilitam a circulação de uma memória de sentidos.

Da nossa perspectiva teórico-metodológica (PÊCHEUX, 1997b; ORLANDI, 1998, 2010), pelo trabalho da ideologia, a linguagem apresenta-se imaginariamente como transparente, como "conteúdo", que poderia ser extraído da forma linguística. Essa "ilusão de conteúdo", como afirma Orlandi (1998), apaga a produção discursiva do referente e dissimula sua construção imaginária de um efeito de unidade, produz esquecimentos inerentes ao discurso. Por meio desses esquecimentos, o sujeito se toma

\footnotetext{
${ }^{3}$ Recentemente, tendo em vista o cenário de ascensão de governos de extrema-direita em diversos países — inclusive no Brasil - e os riscos que tais projetos políticos representam para a democracia, assistimos ainda à emergência de torcidas autodeclaradas antifascistas, que militam pelas liberdades democráticas que se encontram ameaçadas. Algumas dessas torcidas registradas no Facebook são a Palmeiras Antifascista, Avai Antifascista, Fluminense Antifascista e Santos FC Antifascista.

${ }^{4}$ Cf. Pêcheux (1997b).

${ }^{5}$ Em outro trabalho (ZOPPI-FONTANA, 2002, p. 16), afirmamos que a problemática abordada pelo conceito de lugares de enunciação refere-se a "uma reflexão sobre a divisão social do direito de enunciar e a eficácia dessa divisão e da linguagem em termos da produção de efeitos de legitimidade, verdade, credibilidade, autoria, circulação, identificação, na sociedade".
} 
como origem do seu dizer (quando, ao contrário, retoma sentidos pré-existentes) e "esquece" que tudo que disse poderia ser reformulado, dito de outro modo. Em suma, o trabalho ideológico, em sua relação com o político, o social e a história, dissimula o seu funcionamento e produz efeitos de evidência e de transparência da linguagem, que apagam o caráter material dos sentidos.

Mas a língua se inscreve na história para significar e os sentidos se produzem em condições específicas, em estreita relação com a exterioridade. Por essa razão, é fundamental pensar as condições de produção do tweet do Corinthians, que em nossa análise, compreendem a cis-heteronormatividade enquanto norma regulatória e a emergência das páginas de torcidas queer de futebol, em meados de 2013. A reivindicação dessas torcidas pelo direito de ser, torcer e dizer joga luz para os processos históricos de exclusão e chama para a mobilização diferentes setores da sociedade, que passam a exigir da diretoria dos clubes e dos patrocinadores uma postura atuante contra a problemática da LGBTIfobia nos estádios. Além disso, na agenda política, em 2011 tivemos, no Brasil, a aprovação da união estável entre casais homossexuais ${ }^{6}$; e em 2014, as ameaças de punição da FIFA (Federação Internacional de Futebol) as manifestações homofóbicas ${ }^{7}$, devido ao fato do país, naquele ano, sediar a Copa do Mundo. Em nossa análise, buscamos ressaltar como as contradições da exterioridade intervêm na textualidade, como interdiscurso: "algo fala sempre antes, em outro lugar, independentemente, isto é, sob o domínio complexo da ideologia". (ORLANDI, 1998, p. 97).

Em suma, mais do que nos determos sobre o gesto de interdição do grito homofóbico em si, é do nosso interesse investigar os movimentos discursivos envolvidos na tentativa de convencimento do leitor-torcedor sobre a necessidade de interdição do insulto. Para isso, levamos em conta que o sujeito do discurso é uma "posição" - e não o organismo empírico —, e que essas posições são lugares representados no discurso. Essas representações de si e do outro, tratadas como formações imaginárias (PÊCHEUX, 1997a), constituem as condições de produção do discurso e, como defende Cestari (2016), produzem força argumentativa. Isso porque os lugares a que essas representações são atribuídas são determinados na estrutura da formação social, que é capitalista; portanto, marcada pelas relações de força e pela luta de classes. Tais relações, por sua vez, determinam as condições de legitimidade que atravessam a produção discursiva dos locutores: "Quem sou eu para lhe falar assim?" "Quem é ele para que eu the fale assim?".

Para Pêcheux (1997a), as formações imaginárias se definem como lugares que os interlocutores se atribuem no jogo discursivo, a partir das representações que cada um faz do próprio lugar social e do lugar social do sujeito com quem fala. Nesse sentido, a construção da própria identidade imaginária pelo Corinthians é parte do jogo discursivo pelo convencimento, e enquanto discurso, se inscreve na história. Como afirma Orlandi (1998), o sujeito não tem acesso direto a suas intenções, pois estas já

\footnotetext{
${ }^{6}$ STF aprova por unanimidade união estável entre gays. O Globo. 05/05/ 2011. Disponível em: $<$ https://oglobo.globo.com/politica/stf-aprova-por-unanimidade-uniao-estavel-entre-gays-2773489> Acesso em 10 fev 2020.

${ }^{7}$ A FIFA ameaça o México pelos gritos homofóbicos de sua torcida. El País Brasil. 19/06/2014. Disponível em: <https://brasil.elpais.com/brasil/2014/06/19/deportes/1403202374_718317.html> Acesso em $10 \mathrm{fev}$ 2020.
} 
foram "determinadas no nível da constituição do discurso em que as posições do sujeito já foram definidas por uma relação desigual e contraditória com o dizer", de maneira que o sujeito "produz seus argumentos sob o efeito da sua ilusão subjetiva efetuada pela vontade da verdade, pelas evidências do sentido. Os próprios argumentos são produtos dos discursos vigentes, historicamente determinados" (ORLANDI, 1998, p. 78-9). Contraditoriamente, em uma formação social em que a cis-heteronormatividade é construída como forma privilegiada de experiência dos sujeitos, o clube paulistano, de uma posição institucional, argumenta em direção contrária aos discursos dominantes, em um contexto de pressão de órgãos públicos e de movimentos sociais para que se adote uma posição contra a homofobia. A contradição possibilita o surgimento de rachaduras discursivas nessa posição contra a homofobia, por onde o discurso dominante "vaza", e de maneira que a argumentação, produzida sob o efeito dos esquecimentos/da ilusão subjetiva, se expõe aos deslizamentos e ao equívoco.

\section{NOTAS SOBRE O FUTEBOL CONTEMPORÂNEO: AS DEMANDAS POR LEGITIMIDADE NO DISCURSO}

A proposta do Corinthians de interditar o grito de "bicha" não é um momento isolado na história recente do futebol ${ }^{8}$, mas foi uma das primeiras tentativas institucionais realizadas por um clube da primeira divisão de conscientizar seus torcedores com relação à problemática da homofobia no futebol brasileiro. Dois anos depois, em 2016, torcedores palmeirenses organizaram uma iniciativa denominada Movimento 20-99 , que tinha como objetivo convocar os torcedores para substituir o grito de "bicha" nos estádios pelo de "porco", uma vez que o animal é mascote do clube. O movimento, que tinha como primeiro teste a partida do Palmeiras contra o Sport, contou com a presença dos administradores da página Palmeiras Livre no setor Superior Sul do estádio, e buscava o incentivo ao desempenho do clube em campo como alternativa para a legitimação da homofobia. Assim, nessa tese, a proposta do grito de "porco" interpelaria os torcedores por uma filiação discursiva outra no que se refere a seus efeitos de sentido, pois fundaria dizeres que norteariam diferentes valores, posturas e atitudes dentro dos estádios. (MEDEIROS, 2019).

A substituição por "porco" incentiva o torcedor a gritar para celebrar o time, e com isso, desvia a utilização do grito homofóbico, mas não resolve o problema da homofobia nos estádios. Os discursos de filiação homofóbica podem continuar circulando ainda que o grito de "bicha" seja interditado, pois os sentidos se sedimentam pela repetição e reverberação das relações de dominação que subordinam determinados grupos/sujeitos. Pode-se interditar o significante, mas os sentidos homofóbicos resistem pois estão inscritos na história.

Por outro lado, esses movimentos de intervenção na língua produzidos por alguns movimentos sociais nos interessam pois, embora no quadro teórico da Análise do Discurso rejeitemos uma coincidência entre palavra/significado, a produção reiterativa de

\footnotetext{
${ }^{8}$ Vale lembrar que, no ano de 2019, a homotransfobia foi criminalizada no Brasil pelo STF (Supremo Tribunal Federal), e por isso, nos dias atuais, o grito de "bicha" por parte das torcidas pode acarretar multa e perda de pontos na tabela para os times envolvidos.

${ }^{9}$ O nome do movimento alude ao título histórico do Palmeiras no dia 20 de setembro de 1942, data também conhecida como dia da Arrancada Heroica.
} 
dizeres/representações negativas sobre grupos historicamente subalternizados pelos discursivos dominantes preenche de sentidos pejorativos palavras como "bicha", "macaco", "traveco", "vadia" etc. Ao mesmo tempo, temos também a reivindicação dos movimentos sociais para ressignificar algumas dessas palavras, como "bicha" e "vadia"10, para produzir ruptura com a historicidade dos sentidos repetidos e consolidados pela força reiterativa dos discursos dominantes. Esse aspecto já era tratado por Butler (2002) em Críticamente subversiva: ao deter-se sobre os usos da palavra "queer" como insulto, a autora analisa como há um eco de interpelações passadas, como se todos os falantes insultassem em uníssono através do tempo. É no encontro da língua com a história que esses sentidos são constituídos e retomados no fio interdiscursivo, validando a exclusão social e a interdição discursiva. Tal como afirmamos (ZOPPI-FONTANA, 2015, p. 227) em artigo em que abordamos a proposta de um uso não sexista da linguagem, entendemos que se trata de "um debate sobre os efeitos ideológicos das práticas linguísticas e sobre a natureza política do uso da linguagem", em estreita relação com a "denúncia dos efeitos sociais e ideológicos do uso de formas linguísticas (lexicais e morfológicas) que reproduzem e reforçam representações preconceituosas".

A campanha empreendida pelo Movimento 20-9 foi bem-sucedida com relação ao que se propôs. Como foi comunicado ${ }^{11}$ pelos administradores da Palmeiras Livre, a torcida não gritou "bicha" durante as cobranças de tiro de meta. Porém, tampouco entoou o grito de "porco": fez-se silêncio. Um silêncio que, como reconhece a página, não significa necessariamente um avanço, pois seria um silêncio comum às cobranças de tiro de meta em partidas de futebol. Em nossa leitura (MEDEIROS, 2019), não pensamos que esse silêncio seja "comum", mas produzido pela situação de interdição, e só pode ser compreendido se retomamos os processos discursivos que constituem o futebol como um espaço de significação predominantemente cis-heteronormativo; portanto, avesso às existências queer, às performances de gênero e sexualidades consideradas transgressoras, diferentes. Desse modo, quando interditado o grito de "bicha" se faz silêncio, como se a interdição produzisse uma lacuna na linguagem, um vazio antes ocupado pela livre circulação dos dizeres homofóbicos. Esses dizeres podem ser interditados, mas os sentidos permanecem ali, no "silêncio sustentado pela proibição de sentidos fundantes da relação de muitos torcedores com o futebol" (MEDEIROS, 2019, p. 72-3), perpetuando estereótipos discursivos como o de que o futebol é um esporte feito para/por homens cisheterossexuais. Um insulto como "bicha" dentro dos estádios atua nessa direção, dizendo quem são os sujeitos legitimados para jogar o esporte e quem não são, mas a homofobia no futebol pode aparecer de outras formas: pela recusa da diretoria ou resistência da torcida com relação à contratação de um jogador assumidamente homossexual, por exemplo; ou ainda praticada extracampo, por jornalistas esportivos ou ex-jogadores celebrados como ídolos. Na próxima seção, nos deteremos mais atentamente sobre a relação entre cis-heteronormatividade e futebol, que em nossa análise configura as condições de produção da publicação corinthiana.

\footnotetext{
${ }^{10}$ Cf. Chaves (2015).

11 A postagem, realizada em 23 de outubro de 2016, pode ser conferida na íntegra no link: < https://m.facebook.com/story.php?story_fbid=1262745357100478\&id=523788454329509> Acesso em 12 fev 2020.
} 


\section{CIS-HETERONORMATIVIDADE, POLÍTICA DO SILÊNCIO E A ANÁLISE DO DISCURSO}

Tal como Fátima (2019, p. 14) em seu trabalho sobre o discurso religioso e expressão de gênero, compreendemos como condição de produção do material a ser analisado "o funcionamento da heteronormatividade como produto da história em sua construção ideológica". A heteronormatividade é entendida por Miskolci (2009, p. 156) como um conjunto de prescrições que "expressa as expectativas, as demandas e as obrigações sociais que derivam do pressuposto da heterossexualidade como natural e, portanto, fundamento da sociedade", e que, portanto, para além de determinar quem são os sujeitos legítimos/normalizados (e por oposição, também aqueles que não são), interpela todos os sujeitos a organizarem suas vidas segundo esse modelo que se pretende coerente, superior e natural.

À palavra "heteronormatividade", optamos por acrescentar o prefixo "cis-" de modo a destacar, nesse processo, também a cis-normatividade enquanto "imposição de que deva existir coerência linear entre a materialidade do corpo de alguém (órgãos genitais), o gênero designado ao nascer, e a expressão de gênero que a pessoa apresentará ao longo da vida". (JARDIM, 2016, p. 11). Os sentidos normativos produzidos sobre os corpos que, de alguma forma, não se adequam às expectativas da cis-heteronormatividade são regularizados na memória discursiva, na medida em que a ideologia opera o efeito de evidência (PÊCHEUX, 1997b) e os sentidos negativos se naturalizam por repetição.

De uma perspectiva discursiva, os indivíduos são interpelados em sujeitos pelo processo de interpelação ideológica, que é sempre-já-gendrado, isto é, sobredeterminado pelas identificações simbólicas de gênero e sexualidade. (ZOPPI-FONTANA; FERRARI, 2017). Dessa forma, os sujeitos são interpelados em homens/mulheres, heterossexuais/homossexuais, entre outras categorias de identificação, a partir dos sentidos fornecidos pela formação ideológica dominante sobre o que é ser homem e o que é ser mulher, o que é ser hétero e o que é ser não-hétero. O conceito de formação ideológica é definido por Haroche, Pêcheux e Henry (2008, s./n.) como um "conjunto complexo de atitudes e de representações que não são nem 'individuais' e nem 'universais', mas que se relacionam mais ou menos diretamente a posições de classes em conflito umas em relação às outras", e por isso, refere-se ao estado das relações de dominação entre classes em uma formação social. Se em nossa formação ideológica a cisheteronormatividade é construída como modelo privilegiado e natural, os sujeitos são interpelados por tais sentidos normativos com relação às expressões de gênero/sexualidade. Nesse processo, os sujeitos podem reproduzir a norma cisheteronormativa ou produzir rupturas, fazendo emergir sentidos e formas de identificação que desregularizam as repetições históricas.

O futebol é um campo discursivo em que as práticas discursivas cisheteronormativas encontram-se fortemente arraigadas ao imaginário de como deve ser um torcedor ou jogador de futebol. Em seu trabalho, Pinto (2017) analisa como a reiteração e a grande proliferação dos discursos de que os homens são natural e superiormente aptos a jogar futebol naturaliza o homem cis-heterossexual como participante e interlocutor legítimo desse esporte. Em nossa pesquisa (MEDEIROS, 2019), abordamos o funcionamento de alguns desses discursos, a exemplo de quando, em 
2017, o apresentador Carlos Massa e o produtor Arnaldo Saccomani disseram ${ }^{12}$ não ver graça em assistir a mulheres jogando futebol, pois seria como ver homens dançando pole dance. No mesmo ano, o ex-presidente do Vasco, Eurico Miranda, afirmou ${ }^{13}$ que era contra a atuação de árbitros gays, pois eles favoreceriam o time de seus namorados. Embora não seja nosso objetivo nos deter exaustivamente sobre essas formulações, proferidas como senso-comum por apresentadores, técnicos, (ex-)jogadores e jornalistas esportivos, importa destacar a repetição de uma ideia: a de que mulheres e pessoas LGBTI+, de alguma forma, não seriam profissionais tão bons quanto homens cisheterossexuais.

Nesse ponto, retomamos Pêcheux (1997b), que ao conceituar sobre as formações imaginárias, tratou-as também como as representações dos lugares sociais ocupados pelos sujeitos ao falarem, lugares - em que incluímos as identificações de gênero/sexualidade - socialmente divididos e com diferentes graus de legitimidade. Por isso, como observa Cestari (2015), para os movimentos identitários as imagens de quem diz são fundamentais para se constituir a legitimidade do dizer, de modo que se busca consolidar imagens positivas e contradominantes sobre sujeitos/grupos historicamente invisibilizados e silenciados. Esse silenciamento é compreendido por nós a partir do que Orlandi (2007) denomina como política do silêncio; isto é, processo em que se apaga sentidos considerados "indesejáveis" em dada situação discursiva e em que se produz o interdito. Tal como analisa Cestari (2015, p. 138, grifo da autora), entendemos que

há uma política do silêncio pelo fato de os discursos dominantes apagarem sentidos possíveis e indesejáveis para o rompimento do status quo, de seus privilégios de classe-gênero-raça assim como a divisão social e material da enunciação não possibilita que todos ocupem os mesmos lugares de poder-dizer, seja na universidade, no legislativo, nos meios de comunicação, na literatura etc.

Essa discussão pode ser expandida ao futebol, como outro lugar em que a participação de determinados sujeitos é indesejável e limitada pelos processos discursivos que objetivam a manutenção do status quo; a exemplo do grito de "bicha", que faz ecoar os sentidos normativos que tomam sexualidades não-heteronormativas como transgressoras e não legítimas para a prática do esporte. Dessa forma, é relevante o questionamento das imagens estabilizadas sobre pessoas LGBTI+ pelo efeito ideológico de evidência, pois a ilusão de transparência da linguagem e da história apaga a interpretação, de forma que as determinações históricas se apresentam como naturais e imutáveis. A naturalização de sentidos normativos sobre o corpo, materializados pelos discursos dominantes cis-heteronormativos consolidados pelo viés da repetibilidade, dissimula as assimetrias e silencia as formações discursivas dissidentes. Para situar a noção de formação discursiva, retomamos Haroche, Pêcheux e Henry (2008, s./n.), para quem as formações ideológicas "comportam necessariamente, como um de seus componentes, uma ou várias formações discursivas interligadas, que determinam o que pode e deve ser dito [...] a partir de uma posição dada numa conjuntura dada". No processo

\footnotetext{
${ }^{12}$ Ratinho diz ser contra mulher jogando futebol: "Não vejo graça”. UOL Notícias. 2017. Disponível em: $<$ noticias.bol.uol.com.br/ultimas-noticias/entretenimento/2017/10/31/ratinho-diz-ser-contra-mulherjogando-futebol-nao-vejo-graca.htm> Acesso em 12 dez 2018.

${ }^{13}$ Questionado sobre árbitros gays, Eurico Miranda dispara: 'Tende a ajudar o namorado'. Extra. 2017. Disponível em: <https://extra.globo.com/esporte/vasco/questionado-sobre-arbitros-gays-eurico-mirandadispara-tende-ajudar-namorado-20890766.html> Acesso em 12 dez 2018.
} 
de interpelação pela ideologia, os sujeitos inscrevem-se em determinadas formações discursivas que se interligam à formação ideológica a que são correspondentes. Essas formações discursivas podem desenvolver relações de repetição ou ruptura com os discursos dominantes materializados pela formação ideológica.

É pelo trabalho da ideologia e seu viés de repetibilidade que se sustenta a evidência ideológica de que não há espaço para mulheres ou pessoas LGBTI+ no futebol, já que jogar futebol não seria "natural" para esses sujeitos ("não haveria graça", "beneficiariam o time de seus parceiros"), mas sim para homens cis-heterossexuais. Isso também foi observado, de maneira paradoxal, em um relato escrito por um internauta para uma matéria ${ }^{14}$ do Buzzfeed Brasil sobre a relação de homens gays/bissexuais com o futebol. No relato, nos chamou a atenção o fato de o usuário, que se identifica como torcedor, ter se sentido vítima de preconceito pela própria comunidade LGBT+ (que tomaria o futebol como essencialmente heteronormativo), e não só dos seus colegas de equipe (que achavam que ele não entendia de futebol). É um movimento contraditório, que mostra como pessoas LGBT+ são constituídas pelos sentidos que são construídos sobre elas, e como os sentidos normativos são incorporados, internalizados $\mathrm{e}$ naturalizados de tal maneira que o futebol passa a ser entendido como um espaço que não deve ser ocupado por determinados grupos. Considerando a discussão até aqui realizada, analisamos na seção seguinte o manifesto publicado pelo Corinthians em defesa do fim do grito de "bicha" nos estádios, buscando mapear as imagens construídas e projetadas pelo clube paulistano, em sua relação com os discursos dominantes cis-heteronormativos.

\section{O MANIFESTO CORINTHIANO}

O corpus de análise é uma publicação ${ }^{15}$ realizada pelo S. C. Corinthians em seu perfil oficial no Twitter. Com a legenda "manifesto", uma imagem foi postada com os seguintes dizeres:

Manifesto

Aqui é o Time do povo.

Do povo e para o povo.

Desde 1910, aqui se combateu o elitismo e o racismo.

Aqui houve pioneirismo na inclusão social e racial.

Aqui não tem pobre, rico, negro ou branco.

Aqui somos todos Corinthians.

Aqui nos engajamos para ir às ruas e brigar pelas "Diretas Já" em um movimento inédito e histórico que uniu futebol e democracia.

Como fazemos na arquibancada e em campo, aqui lutamos até o fim para que todos sejam iguais.

E aqui não há, nem pode haver, homofobia. adversário.

Pelo fim do grito de "bicha" no tiro de meta do goleiro

\footnotetext{
${ }^{14}$ A matéria, intitulada 16 homens gays e bis contam como é sua relação com futebol e publicada em 2018 , pode ser acessada no link: <https://www.buzzfeed.com/br/raphaelevangelista/homens-gays-futebolhomofobia-lgbt> Acesso em $23 \mathrm{dez} 2019$.

${ }^{15}$ A publicação pode ser acessada no link: <https://twitter.com/Corinthians/status/510439098893742080> Acesso em 13 fev 2020.
} 
Porque a homofobia, além de ir contra o princípio de igualdade que está no DNA corinthiano, ainda pode prejudicar o Timão.

Aqui é Corinthians!

Para o movimento analítico, será mobilizado um conjunto de sequências discursivas, que se definem como "sequências lingüísticas nucleares, cujas realizações representam, no fio do discurso (ou intradiscurso), o retorno da memória (a repetibilidade que sustenta o interdiscurso)". (MARIANI, 1996, p. 54). Nesse movimento de recorte, buscamos nos atentar para os sentidos repetidos/silenciados que intervêm no fio do discurso e para como a posição sujeito do clube é projetada imaginariamente para se defender o fim do grito de "bicha".

Em matéria publicada no dia 12 de setembro de 2014, a Folha de S. Paulo noticiou a divulgação do manifesto pelo Corinthians no Twitter e relembrou que, após o jogo do dia 9 de março contra o São Paulo F. C., a coordenação de políticas LGBT da prefeitura de São Paulo havia protocolado um pedido de punição do clube corinthiano junto ao Tribunal de Justiça Desportiva do Estado $^{16}$. Em junho do mesmo ano, como dito anteriormente, a FIFA ameaçava punir o México pelos cânticos homofóbicos ecoados por sua torcida na Copa do Mundo realizada no Brasil. Esses acontecimentos compreendem as condições de produção mais imediatas à publicação do clube, que retornam sob efeito de memória e constituem discursivamente a maneira como o time designa sua postagem: como "manifesto".

É interessante notar que não se trata de uma "nota de repúdio" contra os gritos proferidos pela própria torcida, e não se trata também de uma "nota de esclarecimento" que buscasse justificar o posicionamento do clube contra o insulto homofóbico. O clube declara sua intenção de expressar um certo posicionamento político/social a partir do que ele próprio designa como "manifesto", que funciona performativamente como apelo ou convocação para o outro se identificar e se unir. Além disso, tal designação recupera redes de significação que constituem a ideia histórica de "manifesto": como inovação, luta e revolução. Historicamente, a publicação de manifestos está relacionada à intenção de se romper com uma ordem estabelecida. Podemos pensar no Manifesto Antropofágico, escrito por Oswald de Andrade, que propunha um outro olhar para a produção artística brasileira, a qual se espelhava nos movimentos europeus; ou no Manifesto Comunista, de Marx e Engels, que estabeleceu os pilares de um movimento crítico à exploração das classes populares pela burguesia e à expansão do capitalismo. Tal caráter de manifestos em geral produz efeitos de sentido desejáveis para a imagem do clube, por meio dos quais o Corinthians se constitui imaginariamente como um clube de vanguarda e alinhado a determinadas reivindicações e lutas políticas. Observemos como a constituição dessa imagem é reforçada nas primeiras sequências discursivas:

SD1: Aqui é o Time do povo.

SD2: Do povo e para o povo.

\footnotetext{
${ }^{16}$ Corinthians divulga manifesto e pede fim de grito de 'bicha' em tiro de meta. Folha de S. Paulo. 2014. Disponível em: <https://www1.folha.uol.com.br/esporte/2014/09/1515081-corinthians-divulga-manifestoe-pede-fim-de-grito-de-bicha-em-tiro-de-meta.shtml> Acesso em 15 fev 2020.
} 
Nas SDs 1 e 2, o Corinthians constrói uma identidade imaginária como time que não é só "do povo", mas também "para o povo". Por esse movimento, produz-se uma imagem de comprometimento com os interesses populares, mas o nome "povo" é opaco: De que "povo" se está falando? Quem está incluído como "povo"? E quem não está?

Vejamos as próximas sequências:

SD3: Desde 1910, aqui se combateu o elitismo e o racismo.

SD4: Aqui não tem pobre, rico, negro ou branco.

SD5: Aqui somos todos Corinthians.

A partir da SD3, a construção imaginária do clube como popular é contraposta ao elitismo e ao racismo, construídos como problemas combatidos pelo clube. É interessante fazer dois principais apontamentos: primeiro, que o clube justifica sua posição como "time do povo" devido à posição histórica de combate ao elitismo e ao racismo; nesse sentido, o Corinthians é o time do povo porque combateu o elitismo e o racismo. A preposição "desde" sustenta essa posição temporalmente e a articula às origens do clube paulistano, fundado em 1910. Dessa forma, não seria possível questionar o comprometimento do Corinthians com as causas sociais, já que elas são naturalizadas como concomitantes ao clube desde o momento da sua fundação, fixadas como sentidos já-lá. Como veremos nas próximas SDs, esse movimento discursivo é amparado na concepção ingênua de que as assimetrias sociais que comportam a formação social brasileira deixam de existir no interior do clube. Não se poderia, assim, associar ao clube opressões históricas como o racismo e o elitismo, pois ele apenas é o "time do povo" porque nele as divisões de raça ou classe foram não só combatidas, mas anuladas.

O segundo apontamento é a ausência de sujeito frasal. Quando se diz "aqui se combateu", o dêitico "aqui" em uma postagem do Corinthians mostra que o combate ao elitismo e ao racismo se deu dentro do/no clube, mas quem é o agente dessa ação? Por ter sido realizada dentro do clube, essa forma impessoal sugere um "nós coletivo", mas há uma mudança significativa na enunciação a partir da SD5, em que se utiliza, de fato, a primeira pessoa do plural. Voltemos a esse ponto mais adiante neste artigo.

Vejamos as SDs 4 e 5. Percebe-se que o funcionamento da palavra "povo" é necessariamente opaco, pois é produzido pela posição sujeito do clube paulistano de modo a apagar as diferenças e divisões sociais. A negação presente na SD4 traz como pré-construído ${ }^{17}$ que há pobres, ricos, negros e brancos, mas não no clube, onde essas diferenças são abdicadas em prol de uma concepção homogênea de "povo", com sujeitos unicamente identificados com o Corinthians. O clube se constitui imaginariamente, então, como não-político, isto é, como não submetido às divisões sociais constitutivas da sociedade capitalista, que fazem funcionar relações de poder simbolizadas. (ORLANDI, 2014). As diferenças são suprimidas para se produzir um efeito imaginário de "nós corinthianos", e a partir desse gesto, como analisa Garcia e Sousa (2018, p. 2893),

17 Segundo Pêcheux (1997b, p. 164), “o 'pré-construído' corresponde ao 'sempre-já-aí' da interpelação ideológica que fornece-impõe a 'realidade' e seu 'sentido' sob a forma da universalidade (o 'mundo das coisas')". 
o "nós" inscreve um efeito imaginário, bastante efetivo diga-se de passagem, de construir uma coletividade, melhor dizendo, um efeito de simetria e inclusão de todos sob a guarda de uma mesma unidade. Criase, pelo efeito ideológico de evidência, um imaginário aniquilamento das diferenças e uma pretensa equivalência de posições, cuja operação silenciaria qualquer desigualdade, discordância ou contradição entre os sujeitos.

Nesse processo, funda-se uma pretensa unidade consensual construída no apagamento do político e da história. Essa tentativa de inclusão, que baseados em Junqueira (2015) chamamos de inclusão periférica, não desestabiliza ou confronta os processos discursivos que historicamente legitimaram a exclusão e o silenciamento, mas oferece "um salvo-conduto que possibilite uma inclusão consentida em um ambiente hostil, uma frágil acolhida". (JUNQUEIRA, 2015, p. 113, grifo do autor). A identificação com o Corinthians passa a ser o elo que unifica todos os sujeitos, sobrepondo-se às divisões sociais e projetando um funcionamento frágil de inclusão.

SD6: Aqui nos engajamos para ir às ruas e brigar pelas "Diretas Já" em um movimento inédito e histórico que uniu futebol e democracia.

$\mathrm{Na}$ SD6, é recuperado um episódio da história do clube conhecido como Democracia Corinthiana, ocorrida entre os anos de 1982 e 1984. À época, o Brasil experienciava a ditadura militar, sob o governo João Figueiredo, e o Corinthians vinha atravessando um período de maus resultados no Campeonato Paulista e no Campeonato Brasileiro. Com a inauguração de um novo modelo de gestão, a Democracia Corinthiana, todas as decisões do clube passaram a ser tomadas por meio de votação, em que dirigentes, atletas e funcionários (desde as posições mais altas até as mais baixas na hierarquia) tinham o voto de mesmo peso. Isso, vale lembrar, em uma época em que foi retirado da população brasileira o direito de escolher seus representantes políticos. Além disso, como explica Rondinelli (201-?), os jogadores entravam em campo vestindo camisetas por baixo da camisa oficial do clube, com dizeres como "Diretas já!" e "Eu quero votar para presidente", atitudes que consolidaram o Corinthians da época como uma força política simbólica contra a ditadura.

Tal episódio é recuperado como um movimento "inédito", que teria unido futebol e democracia. É possível perceber aqui como a ideologia opera de modo a produzir a evidência de que o futebol e democracia nunca tinham se relacionado até que o Corinthians teria unido um ao outro: antes das lutas políticas do clube, o esporte seria essencialmente elitizado, mas o movimento corinthiano teria levado o futebol a se democratizar. Nessa produção discursiva, em estreita relação com a memória, é realizado um recorte da história em que se "esquece" determinados fatos históricos, de modo a consolidar a narrativa que faz incidir sobre a imagem do clube redes de significações que o associam ao popular e às lutas políticas por direitos e reconhecimento. O "esquecido" é o fato de que a profissionalização do futebol foi uma reivindicação das camadas populares para que pudessem se dedicar integralmente ao aperfeiçoamento no esporte, enquanto a elite, contrária à profissionalização, boicotava os jogos das equipes profissionais. (REIS, 2006). Desse modo, a resistência dos trabalhadores é parte da história do futebol profissional e da democratização desse esporte, e precedeu as lutas populares no século XX pelo direito ao lazer. Esse "esquecimento" das tensões entre classes que permeiam a história do futebol é necessário para que o Corinthians se 
constitua imaginariamente como clube popular e de vanguarda, democrático como nenhum outro clube poderia ser.

A busca pelo fortalecimento contínuo dessa imagem do Corinthians é também uma forma de se antecipar a possíveis críticas ao clube pelo posicionamento contra a homofobia nos estádios, levando em conta as condições de produção e a circulação histórica dos dizeres homofóbicos. Em nossa pesquisa (MEDEIROS, 2019), observamos como as páginas de torcidas queer de futebol eram acusadas de "politizar" o futebol, de "invadi-lo" com "frescuras" e o "politicamente correto", como avaliamos:

há um choque entre os discursos produzidos pelas torcidas com sentidos historicamente sedimentados e naturalizados por efeito de evidência, atrelados a uma interpretação do futebol como espaço neutro pela negação das relações de força, contradições e assimetrias que compõem a formação social brasileira (MEDEIROS, 2019, p. 21).

Nesse sentido, entra em jogo também a imagem que o Corinthians constrói do torcedor que grita o insulto homofóbico no estádio: como um sujeito identificado com a cis-heteronormatividade enquanto norma e que acredita que os movimentos sociais reivindicam privilégios, pois já seríamos todos iguais perante a lei. A naturalização da cis-heteronormatividade funda a ilusão de que suas práticas discursivas funcionam como estado neutro da linguagem, e outras práticas que se oponham a ela seriam "invasoras", "doutrinadoras" ou "ideológicas". Contraditoriamente, de modo a preparar seu leitortorcedor para o posicionamento contra a homofobia e favorável ao fim do grito de "bicha", o Corinthians retoma os dizeres sobre igualdade para lembrar-lhe que, no clube, são todos iguais e sempre se esteve envolvido com política; portanto, não estaria tentando "politizar" o futebol. Esses movimentos são realizados para culminar, finalmente, na tomada de posição contra a homofobia:

SD7: E aqui não há, nem pode haver, homofobia.

SD8: Pelo fim do grito de "bicha" no tiro de meta do goleiro adversário.

Chama atenção como a partir da SD7 há uma mudança na enunciação, anteriormente marcada pela primeira pessoa, em "aqui somos" (sexta linha), "aqui nos engajamos" (sétima linha), "aqui lutamos" (nona linha). Quando se menciona a homofobia na SD7, não se lê "aqui somos todos contra a homofobia" ou "aqui lutamos contra a homofobia", mas um enunciado em terceira pessoa (com uso do verbo impessoal "haver") e sem sujeito frasal. Na SD8, também não há sujeito frasal: quem é pelo fim do grito de "bicha" nos estádios? O grito é de quem? E para quem? Essas substituições pronominais e esse jogo entre a sintaxe e a morfologia mostram a contradição, que faz "vazar" o discurso cis-heteronormativo: ao mesmo tempo que se faz uma campanha contra a homofobia, não se enuncia ocupando como locutor (sujeito da enunciação) uma posição não homofóbica. O clube poderia dizer "aqui nos engajamos na luta contra a homofobia", mas não diz. Se nos aliamos à análise de Indursky (1992) sobre a indeterminação do referente, é possível dizer que a inexistência do referente no discurso (grito de quem? para quem?) é fundamental para constituir o imaginário de que aqueles que gritam não são muitos, mas uma minoria pouca expressiva, que não afeta o imaginário de unidade democrática construído pelo clube. 
É nesse sentido que a posição discursiva contra a homofobia e a imagem do clube como progressista são construídas de forma paradoxal: o clube nega a existência da homofobia em seu interior (SD7) e ao mesmo tempo defende o fim do insulto homofóbico em cobranças de tiro de meta (SD8), o que dá a entender que existe homofobia em algum lugar, mas não no Corinthians, onde todos seriam iguais. A defesa do fim do grito de "bicha" não se dirige explicitamente aos próprios torcedores, de modo que esse tratamento genérico permite que se desvalorize a ideia de que exista homofobia dentro do clube ou que o clube seja homofóbico.

Argumentamos, assim, que o clube se inscreve em uma posição sujeito que deve ser analisada tomando em conta o seu assujeitamento à formação ideológica dominante cis-heteronormativa. Esse assujeitamento não se dá à maneira de uma identificação plena com os dizeres normativos, uma vez que é defendido que não se deve clamar insultos homofóbicos ou reproduzir homofobia, mas falha ao romper completamente com eles. Desse modo, observando que relações interdiscursivas se estabelecem com outros discursos, realiza-se uma tentativa de dissimular a existência da contradição pela produção de uma ambiguidade equívoca própria do funcionamento de discursos como o dos Direitos Humanos, que paira como modelo a ser seguido pelas democracias liberais do nosso tempo.

A discursividade dos Direitos Humanos, que precede a luta LGBTI+ tal como organizada a partir da década de 60, remonta à Revolução Francesa e à Declaração dos Direitos do Homem e do Cidadão. Embora não seja o foco do nosso trabalho analisar a constituição histórica desse discurso, cabe dizer, com base nos estudos de Orlandi (2017) sobre o tema, que as explorações e assimetrias operadas no sistema capitalista não existem por mera falha ou acaso, mas porque é assim que ela se estrutura e funciona. $\mathrm{O}$ discurso histórico dos Direitos Humanos se funda em um momento crítico para a sociedade democrática burguesa (após o fim da II Guerra Mundial) e instaura condições para que discursos 'outros' possam irromper na ideologia dominante, absorvendo as resistências de modo a não mexer nas estruturas, e mesmo para não mexer nas estruturas. É discurso instrumentalizado para que a ordem dominante tenha, no máximo, que reacomodar-se; e que domestica as resistências contra o racismo, a opressão às mulheres, às comunidades indígenas, às diversas religiões etc.

Esse modo de docilizar o encontro com o contraditório, tal como mobilizado no discurso do manifesto pela projeção de imagens de unidade que visam administrar a ambiguidade equívoca, busca suavizar as fissuras produzidas pelo confronto entre: (1) as torcidas queer, movimentos sociais e importantes entidades/instituições públicas (alinhadas contrariamente ao discurso homofóbico), e (2) os torcedores, jornalistas e figuras públicas identificadas com a cis-heteronormatividade, que rejeitam a existência dos preconceitos e assimetrias, já que todos são iguais (alinhamento ao discurso homofóbico). Nesse processo, a posição sujeito ocupada pelo clube projeta por antecipação um consenso aparente como forma de arrefecer a luta de classes entre seus torcedores e promover a desejada unidade, e aqui voltamos às SDs 4 e 5 . Retomando os estudos de Indursky sobre a determinação discursiva, que "consiste no trabalho discursivo de determinação do que pode/deve ser dito, bem como do que pode, mas não convém ser dito e ainda do que não pode ser dito" (INDURSKY, 1992, p. 357), é possível perceber como se projeta um torcedor corinthiano que fecha o imaginário e produz o efeito de homogeneidade: ele não é pobre, rico, negro ou branco. Sobretudo, em um 
manifesto contra um grito homofóbico, há o não-dito referente à existência de corinthianos gays, corinthianos queers, corinthianos/as/es trans, corinthianas lésbicas, etc. que silencia as divisões que estruturam uma formação social dominada pela cisheteronormatividade.

SD9: Porque a homofobia, além de ir contra o princípio de igualdade que está no DNA corinthiano, ainda pode prejudicar o Timão.

$\mathrm{Na}$ análise da SD9, é possível observar como o discurso dominante cisheteronormativo, camuflado pela produção do consenso aparente, "vaza" novamente no processo discursivo pela relação escalar estabelecida entre os argumentos. Dois argumentos contra a homofobia são construídos no enunciado: $\mathrm{O}$ primeiro argumento (A1) refere-se à asserção de que a homofobia iria contra o princípio da igualdade adotado pelo Corinthians, e o segundo argumento (A2) à possibilidade de o time ser punido pelos gritos homofóbicos. Em A2, retorna como memória tanto a denúncia protocolada pela Prefeitura de São Paulo quanto as ameaças da FIFA, de modo que se espera que, caso A1 não convença o interlocutor de que não se deve gritar "bicha" no estádio, A2 o faça. Esse efeito é produzido pelo termo "ainda", que introduz um argumento de caráter decisivo para se somar ao primeiro argumento trazido, construído como mais fraco. Uma vez que o Corinthians é construído imaginariamente como um time homogêneo, cujos torcedores não são pretos ou brancos, ricos ou pobres, mas apenas corinthianos, espera-se que os torcedores abdiquem do insulto homofóbico, senão porque ser homofóbico é ser contra a igualdade, então pelo bem-maior do clube paulistano, o elemento que unifica toda a torcida.

Observamos, assim, mais uma vez, uma construção discursiva que projeta o clube como exterior às divisões que compõem a formação social brasileira, e por isso, como instituição capaz de pacificar as diferenças, silenciadas pela identificação única e determinante com o Corinthians. É importante dizer que esse gesto serve aos interesses do discurso dominante, pois o silenciamento é capaz de suavizar e domesticar as resistências, evitando os deslizamentos e rupturas necessárias para a legitimação e visibilidade de pessoas LGBTI+ no esporte. Pelo silenciamento não há ruptura, legitimação, questionamento ou revolução, há apenas o que sempre houve: os processos regulatórios e normalizadores permanecem os mesmos, com exceção do oferecimento de uma aquiescente autorização para o diferente existir, mas à margem e silenciado. (JUNQUEIRA, 2015).

\section{CONSIDERAÇÕES FINAIS}

Neste artigo, apresentamos alguns dos resultados obtidos em nossa pesquisa monográfica Torcida que canta, vibra e luta (MEDEIROS, 2019), em que analisamos discursivamente páginas de torcidas queer de futebol no Facebook como movimentos de resistência contra sentidos normativos sobre gênero/sexualidade em circulação no futebol. Recuperamos aqui como a ideologia opera o efeito de evidência por meio da repetibilidade, assim, produzindo o efeito de transparência dos sentidos. A cisheteronormatividade, entendida como produto da história e prescrição normativa sobre os corpos, traça uma fronteira de normalidade que separa os sujeitos "normais" daqueles que são relegados à exclusão e ao silenciamento. Tal silenciamento, como tomamos a 
partir de Orlandi (2007), funciona como uma interdição que apaga os sentidos considerados "indesejáveis" em uma dada situação discursiva. No caso, a partir da compreensão da cis-heteronormatividade como condição de produção para a emergência das páginas queer, o "indesejável" seriam os sentidos que abrem brechas discursivas no interior da dominação para produzir os deslizamentos e os equívocos. As torcidas queer instauram lutas políticas por legitimidade e visibilidade no futebol, contra a LGBTIfobia e o machismo que sustentam o homem cis-heterossexual como participante e interlocutor legítimo desse esporte.

Em diálogo com nossa pesquisa, analisamos neste artigo um manifesto publicado pelo perfil oficial do S. C. Corinthians em 2014, em que o clube reivindicava o fim do grito de "bicha" em cobranças de tiro de meta pelo goleiro adversário. $\mathrm{Na}$ análise, nos detivemos sobre a constituição discursiva da imagem do clube ao longo do manifesto, e observamos a projeção frequente de uma imagem atrelada a sentidos de comprometimento com os interesses populares e com as lutas políticas por direitos e reconhecimento. Os torcedores, funcionários e todos aqueles de alguma forma identificados com o clube são entendidos como uma massa homegênea, já que, como diz o manifesto, "aqui não há pobre, rico, negro ou branco". As assimetrias sociais e relações de força existentes não só na formação social brasileira, como em qualquer sociedade capitalista, são apagadas para se produzir um "nós", um efeito imaginário de unidade que produz esquecimento e suprime as diferenças em prol de uma pretensa unidade consensual: o Corinthians.

Nesse movimento, o clube busca suavizar as disputas produzidas pelo confronto entre o discurso homofóbico e as demandas LGBTI+ por legitimidade, que ganharam espaço na agenda social, nos últimos anos. De modo a arrefecer a luta de classes e manter a imagem de time popular entre todo o povo e para todo o povo, a posição sujeito do clube projeta um imaginário de consenso ao negar as assimetrias sociais para justificar o fim do grito de "bicha". Em meio a esse processo contraditório, convém dizer que esse consenso, enquanto inclusão periférica, não confere sentidos de legitimidade a pessoas LGBTI+ e não questiona os processos históricos de dominação/subordinação que sustentam o preconceito e as violências físicas, simbólicas e políticas contra sujeitos que, de alguma forma, não se adequam à norma regulatória cis-heteronormativa.

Por isso, apontamos finalmente a relação contraditória que o consenso e a inclusão periférica estabelecem com as demandas políticas de pessoas LGBTI+ no futebol, produzidas, por exemplo, pelas torcidas queer. No espectro dos discursos dominantes, meramente apontar a "existência da diversidade é suficiente, dentro dessa lógica consensual, para responder aos conflitos sociais, como se lhes dissesse: "nós somos diversos, então não há preconceito aqui'" (MEDEIROS, 2019, p. 118), ao passo que as torcidas queer buscam a desestabilização dos processos históricos que sustentam as políticas do silêncio para se incluir no espaço da cidadania e do direito à torcida. Esse movimento passa pela instauração de dizeres sobre si, de modo a se produzir imagens positivas que rompam com os estereótipos e sentidos negativos construídos sobre pessoas LGBTI+. Nesse sentido, a criação de uma igualdade normativa, que não questiona a ordem cis-heteronormativa e seus sentidos normativos, significa continuar negando às pessoas LGBTI+ o que elas demandam: reconhecimento. 


\section{REFERÊNCIAS BIBLIOGRÁFICAS}

BUTLER, J. Críticamente subversiva. In: JIMÉNEZ, R. M. Sexualidades transgressoras: una antología de estudios queer. Barcelona, ESP: Icaria, 2002. CESTARI, M. J. Vozes-mulheres negras ou feministas e antirracistas graças às Yabás. 2015. Tese de doutorado. Instituto de Estudos da Linguagem (UNICAMP). Campinas/SP. Disponível em: http://repositorio.unicamp.br/bitstream/REPOSIP/271056/1/Cestari_MarianaJafet_D.pd f> Acesso em 09 mar 2019.

CHAVES, T. Da marcha das vadias às vadias da marcha: Discursos sobre as mulheres e o espaço. 2015. Dissertação (Mestrado em Linguística) - Universidade Estadual de Campinas, Brasil.

FÁTIMA, W. S. Discurso, (expressão de) gênero e religiosidade: a mídia impressa neopentecostal em questão. In: FÁTIMA, W. S. (Org.). Por uma análise do discurso sobre o gênero e a sexualidade: efeitos de sentido, ideologias e práticas discursivas em questão. São Paulo, SP: Pimenta Cultural, 2019.

GARCIA, D. A.; SOUSA, L. M. A. E. 'Não pense em crise, trabalhe': o jogo da história na trama da língua. In: Fórum Linguístico, v. 15, p. 2890-2902, 2018.

HAROCHE, C.; PÊCHEUX, M.; HENRY, P. A semântica e o corte saussuriano: língua, linguagem, discurso. Tradução de Roberto Baronas e Fábio Montanheiro. In: $\begin{array}{llllll}\text { Linguasagem, } & \text { n. } & 3, & 2008 . & \text { Disponível } & \text { em: }\end{array}$ http://www.ufscar.br/linguasagem/edicao03/traducao_hph.php> Acesso em 13 fev 2020. INDURSKY, F. A fala dos quartéis e as outras vozes: uma análise do discurso presidencial da Terceira República Brasileira (1964-1984). 1992. Tese (Doutorado) Instituto de Estudos da Linguagem (UNICAMP), Campinas, Brasil.

JARDIM, J. G. Deveriam os estudos queer falar em cis-heteronormatividade? Reflexões a partir de uma pesquisa sobre performatividade de gênero nas artes marciais mistas femininas. In: Anais do \#4 Seminário Internacional de Sexualidade e Educação e \#2 Encontro Internacional de Estudos de Gênero, Vitória-ES, 2016. Disponível em: < http://www.gepsexualidades.com.br/resources/anais/6/1467327007_ARQUIVO_Jardim CisHeteronormatividade.pdf $>$ Acesso em 20 dez 2019.

JUNQUEIRA, R. D. Heteronormatividade e vigilância de gênero no cotidiano escolar. In: RODRIGUES, A.; DALLAPICULA, C.; FERREIRA, S. R. S. (Orgs.). (Trans)posições: lugares e fronteiras em sexualidade e educação. Vitória, ES: EDUFES, 2015.

MARIANI, B. S. C. O comunismo imaginário: práticas discursivas da imprensa sobre o PCB (1922-1989). 1996. Tese (Doutorado em Estudos de Linguagem) - Universidade Estadual de Campinas, Campinas.

MEDEIROS, M. S. Torcida que canta, vibra e luta: um estudo discursivo de páginas de torcidas queer de futebol. Monografia (Licenciatura em Letras) - Instituto de Estudos da Linguagem, Universidade Estadual de Campinas (UNICAMP), 2019. No prelo.

MISKOLCI, R. Teoria Queer: um aprendizado pelas diferenças. Belo Horizonte: Autêntica; UFOP: Universidade Federal do Ouro Preto, 2012.

ORLANDI, E. P. Análise de discurso: princípios e procedimentos. $11^{\mathrm{a}}$ ed. Campinas, SP: Pontes, 2010.

ORLANDI, E. P. As formas do silêncio: no movimento dos sentidos. $6^{\mathrm{a}}$ ed. Campinas, SP: Unicamp, 2007.

ORLANDI, E. P. Discurso e argumentação: um observatório do político. In: Fórum Linguístico, Florianópolis, v. 1, n. 1, p. 73-81, jan. 1998. ISSN 1984-8412. Disponível 
em: <https://periodicos.ufsc.br/index.php/forum/article/view/6915/6378>. Acesso em: 10 fev. 2020.

ORLANDI, E. P. Discurso em análise: sujeito, sentido e ideologia. $3^{\mathrm{a}}$ ed. Campinas, SP: Pontes Editores, 2017.

ORLANDI, E. P. Ser diferente é ser diferente: a quem interessam as Minorias? In: ORLANDI, E. P. (Org.). Linguagem, sociedade, políticas. Pouso Alegre: Univás; Campinas: RG Editores, 2014.

PÊCHEUX, M. Análise automática do discurso (AAD-69). In: GADET, F.; HAK, T. (Orgs.). Por uma análise automática do discurso: uma introdução à obra de Michel Pêcheux. Tradução de Bethania S. Mariani et al. $3^{\text {a }}$ ed. Campinas, SP: Editora da Unicamp, 1997a.

PÊCHEUX, M. Semântica e discurso: uma crítica à afirmação do óbvio. Tradução de Eni Puccinelli Orlandi et al. $3^{\text {a }}$ ed. Campinas, SP: Editora da Unicamp, 1997b.

PINTO, M. R. Pelo Direito de torcer: Movimentos e coletivos de torcedores contrários ao machismo e à homofobia no Futebol. 2017. Dissertação (Mestrado em Ciências) Universidade de São Paulo, USP.

REIS, H. H. B. Futebol e violência. Campinas, SP: Armazém do Ipê (Autores Associados), 2006.

RONDINELLI, P. A Democracia Corinthiana. Brasil Escola. 201-?. Disponível em: $<$ https://brasilescola.uol.com.br/educacao-fisica/a-democracia-corinthiana.htm. $>$ Acesso em 16 fev 2020.

ZOPPI-FONTANA, M. G.; FERRARI, A. J. Apresentação: uma análise discursiva das identificações de gênero. In: ZOPPI-FONTANA, M. G; FERRARI, A.J. (Orgs.). Mulheres em discurso: identificações de gênero e práticas de resistência. $1^{\mathrm{a}}$ ed. Campinas, SP: Pontes, 2017, v. 2.

ZOPPI-FONTANA, M. G. Língua oficial e políticas públicas de equidade de gênero. In: Línguas e Instrumentos Linguísticos, v. 36, p. 221-243, 2015.

ZOPPI-FONTANA, M. G. 'Lugar de fala': enunciação, subjetivação, resistência. In: Conexão Letras, v. 12, p. 63-71, 2017a. Disponível em: $<$ https://seer.ufrgs.br/conexaoletras/article/viewFile/79457/46458> Acesso em 07 mar 2019.

ZOPPI-FONTANA, M. G. Lugares de enunciação e discurso. In: Leitura. Revista do Programa de Pós-Graduação em Letras (UFAL), Maceió, v. 23, n. jan/jun-99, p. 15-24, 2002.

Artigo recebido em: abr. de 2020.

Aprovado e revisado em: jun. de 2020.

Publicado em: julho de 2020.

Para citar este texto:

MEDEIROS, Matheus da Silva; ZOPPI-FONTANA, Mónica G.. O "Time do Povo" e o Discurso da Inclusão Periférica: cis-heteronormatividade, futebol, ideologia. Entremeios [Revista de Estudos do Discurso, ISSN 2179-3514, on-line, www.entremeios.inf.br], Seção Estudos, Programa de Pós-Graduação em Ciências da Linguagem (PPGCL), Universidade do Vale do Sapucaí (UNIVÁS), Pouso Alegre (MG), vol. 21, p. 257-273, jan. - jun. 2020.

DOI: $\underline{\text { http://dx.doi.org/10.20337/ISSN2179-3514revistaENTREMEIOSvol21 pagina257a273 }}$ 